\title{
Spending, saving and borrowing: Perceptions and experiences of girls in Gujarat
}

Population Council

Follow this and additional works at: https://knowledgecommons.popcouncil.org/departments_sbsr-pgy

Part of the Demography, Population, and Ecology Commons, Family, Life Course, and Society Commons, Gender and Sexuality Commons, and the International Public Health Commons How does access to this work benefit you? Let us know!

\section{Recommended Citation}

"Spending, saving and borrowing: Perceptions and experiences of girls in Gujarat," update. New Delhi: Population Council, 2006. 

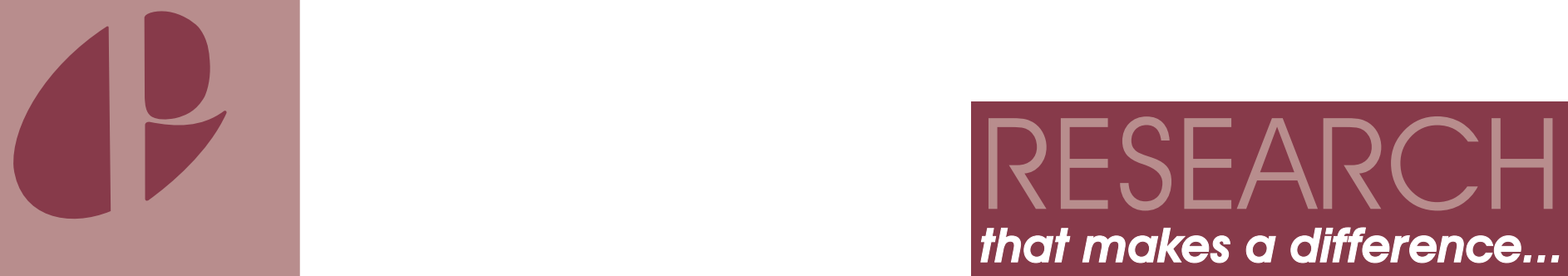

\section{SPENDING, SAVING AND BORROWING: PERCEPTIONS AND EXPERIENCES OF GIRLS IN GUJARAT}

\section{Background}

Microfinance and savings programmes that offer user-friendly and flexible savings schemes for women are increasingly being implemented in India. Such savings programmes have, however, been limited to adult women. While adult women undoubtedly need access to such services, adolescent and young women do too. Adolescent and young women typically make the transition to adulthood with few life options or control over economic resources. Their situation is further exacerbated by the fact that they are less likely than their brothers to be educated or to engage in wage-earning activities; moreover, their mobility, exposure to the outside world, and work options are considerably limited. Although a number of programmes have been implemented that specifically aim to empower adolescent girls and young women, these have largely focused on enhancing life skills and awareness.

The potential among young females to enhance their control over resources through savings and the use of other financial products in formal and informal banking institutions has rarely been addressed, either in research or through programmes. The Council and the Self Employed Women's Association (SEWA) jointly undertook a pilot project that aimed to better understand the perceptions and experiences of adolescent girls with regard to savings and financial literacy.

\section{Description of Project}

Sites: The project was undertaken among adolescent and young married and unmarried women in three settings of Gujarat: one urban district (Ahmedabad), one well-developed rural district (Kheda) and one poorly developed rural district (Banaskantha) in order to maximise differences in economic status and educational levels. SEWA has a significant presence within the state and the selected districts.

Study design: The study was exploratory. Data were obtained through in-depth interviews with 76 adolescent girls and young women (13-25 years), who hold some type of savings account with SEWA. Of these, 46 were the daughters or daughters-in-law of SEWA members; mothers or mothers-in-law of the remaining 30 were members of a SEWA savings group or held an account with the SEWA Bank. Interviews with these girls explored saving patterns, the extent of participation in savings and barriers to savings, the use of savings and degree of autonomy in use of savings, and girls' perceptions and experience with the schemes or accounts they have.

\section{Findings}

The findings suggest that, in general, almost all young people in these resource-poor settings have access to money, either by way of wages and/or gifts. Moreover, there is an interest in savings. the importance of having savings is readily understood by girls and young women. Yet, despite the fact that respondents were chosen because they already held some type of SEWA savings account, the interviews show that rather than being an empowering process, in most instances the girls are passive cosigners who have little or no control over their accounts. Findings indicate the limited decisionmaking authority or control over 
economic resources exercised by young women in general, and with regard to their accounts in particular. Young women were only superficially involved in opening their own accounts, and rarely played an independent role in operating the account or in drawing loans on the basis of the account. By and large, mothers, fathers, and husbands were the main decisionmakers. Sathins (local women engaged by SEWA to mobilise women to save) played a significant facilitating role, not only by raising awareness about the importance of saving but also by supporting young account holders and their mothers to manage their accounts and avail credit facilities. But again, the active and arguably most empowering elements of making decisions regarding what type of account, operating the account, going to the bank, and deciding how savings would be used, were not part of the savings experience for most girls. That said, some of the respondents (in general, older, urban, and better-educated young women) did display control and awareness of their own accounts. These young women were more likely than others to be familiar with banking procedures, to have family support for controlling their accounts and to have specific goals for which they proposed to use their savings. Notably, among those few respondents who were aware of the different types of savings accounts available, all argued for schemes that allowed them greater control (i.e., individual vs. joint accounts) and flexibility (e.g., permitting small deposits, no rigid schedule of deposits). While SEWA offers such schemes, they are either poorly explained or not conveyed to girls/young women by gatekeepers.

\section{Implications for Programmes}

Findings suggest considerable potential and an unmet need for providing meaningful savings products for adolescent girls and young women. As currently implemented, the savings accounts for most of these girls are akin to so many other aspects of their live s i.e., they have little say and little active engagement in the process. To make the savings experience more meaningful and, we believe, make it a more empowering experience for girls, several strategies are recommended. What are needed are, first, financial literacy programmes that are tailored for young adult women and that include easily understandable descriptions of services available. Such programmes might include, for example, units on numeracy, savings options available to girls/young women, the processes and mechanisms implied in opening and operating savings accounts, the facilities associated with the ownership of a savings account in terms of credit options, services for which they are eligible, and the rights to which they are entitled. Second, in order to enable young women to gain control over their savings however, there is also a need for programmes that sensitise parents about the need to develop within the home a savings culture among their daughters and enable them to be able to manage finances, make financial decisions, and operate savings accounts. Such work with gatekeepers would be a vital component of any intervention. Third, there is a need to adapt financial products to suit the needs of adolescent girls and young women, to take into consideration the fact that access to money is irregular for most young women and that even those who are engaged in wage earning activities may not be in a position to save money for themselves on a regular basis. Finally, young female account holders need, in the short run, a savings advocate or mentor to help them become familiar with the banking process and comfortable with such concepts as budgeting, credit, and interest. The key is that the mentor not take over the decisionmaking for the girls, rather that they support the girls in identifying their own needs and making their own decisions.

\section{Suggestions for Future Research}

Findings from this research have raised awareness of the distinct vulnerability and capacities of adolescent girls and their interest in savings and savings products. However, this was a descriptive and exploratory study and findings may not be representative of adolescent and young women in these districts more generally. What is needed is a larger and more representative study that explores the issues raised in this research and evaluates an intervention that, based on these formative research findings and recommendations, aims to enhance savings among adolescent girls and young women in India.
1P Population Council

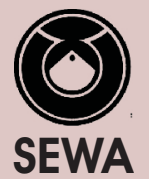

For further information please contact:

Population Council Zone 5A, Ground Floor India Habitat Centre, Lodi Road New Delhi - 110 003, INDIA

Tel: 91-11-2464 2901/02

Fax: 91-11-2464 2903

Email: info-india@popcouncil.org

\section{www.popcouncil.org}

Shveta Kalyanwala, Shireen Jejeebhoy, Sunetra Deshpande, Mary Philip Sebastian, Anjali Widge (Population Council); Jennifer Sebstad (Consultant); Mita Parikh, Bijal Bangdiwala, Jigna Pandya, Rashmi Sharma (SEWA Academy)

\section{Donors}

Department for International Development,

The Ford Foundation,

The Rockefeller Foundation,

Community Foundation for National

Capital Region/The Summit Foundation

\section{Reference}

Kalyanwala, S. and J. Sebstad. 2006. Spending, saving and borrowing: Perceptions and experiences of girls in Gujarat, Research Report. 